\title{
Correspondence
Ralf Koebnik
koebnik@gmx.de \\ Membrane topology of conserved components of the type III secretion system from the plant pathogen Xanthomonas campestris pv. vesicatoria

\author{
Carolin Berger, ${ }^{1} \dagger$ Guillaume P. Robin, ${ }^{2}$ Ulla Bonas ${ }^{1}$ and Ralf Koebnik ${ }^{1,2}$ \\ ${ }^{1}$ Institute of Biology, Department of Genetics, Martin-Luther-University, 06099 Halle, Germany \\ 2Laboratoire Génome et Développement des Plantes, Université de Perpignan via Domitia-CNRS- \\ IRD, UMR 5096, IRD Montpellier, France
}

\begin{abstract}
Type III secretion (T3S) systems play key roles in the assembly of flagella and the translocation of bacterial effector proteins into eukaryotic host cells. Eleven proteins which are conserved among Gram-negative plant and animal pathogenic bacteria have been proposed to build up the basal structure of the T3S system, which spans both inner and outer bacterial membranes. We studied six conserved proteins, termed Hrc, predicted to reside in the inner membrane of the plant pathogen Xanthomonas campestris pv. vesicatoria. The membrane topology of $\mathrm{HrcD}, \mathrm{HrcR}$, HrcS, $\mathrm{HrcT}, \mathrm{HrcU}$ and $\mathrm{HrcV}$ was studied by translational fusions to a dual alkaline phosphatase- $\beta$ galactosidase reporter protein. Two proteins, $\mathrm{HrcU}$ and $\mathrm{HrcV}$, were found to have the same membrane topology as the Yersinia homologues YscU and YscV. For HrcR, the membrane topology differed from the model for the homologue from Yersinia, YscR. For our data on three other protein families, exemplified by $\mathrm{HrcD}$, $\mathrm{HrcS}$ and $\mathrm{HrcT}$, we derived the first topology models. Our results provide what is believed to be the first complete model of the inner membrane topology of any bacterial T3S system and will aid in elucidating the architecture of T3S systems by ultrastructural analysis.
\end{abstract} \\ Accepted 2 April 2010
}

\section{INTRODUCTION}

Type III secretion (T3S) systems have evolved in Gramnegative bacteria to assemble flagella, secrete extracellular proteins, and deliver so-called effector proteins into the cytoplasm of eukaryotic cells. Nonflagellar T3S systems are important pathogenicity determinants and essential for the interaction of most Gram-negative bacterial pathogens with their eukaryotic hosts (Cornelis, 2006; Pallen et al., 2005). T3S systems that transport proteins in a one-step process across the two bacterial membranes and the host plasma membrane directly into the host cell's cytoplasm have been identified in animal pathogens, e.g. Yersinia spp., Salmonella spp., Shigella spp. and Escherichia coli (Coburn et al., 2007), and in most plant pathogens, e.g. Pseudomonas syringae, Ralstonia solanacearum, Erwinia

†Present address: Leibniz Institute of Plant Genetics and Crop Plant Research (IPK), Corrensstraße 3, 06466 Gatersleben, Germany.

Abbreviations: Rose-Gal, 6-chloro-3-indolyl- $\beta$-D-galactopyranoside; T3S, type III secretion; TMS, transmembrane segment; X-phos, 5bromo-4-chloro-3-indolyl phosphate, disodium salt.

A supplementary table, showing the oligonucleotides used in this study, and three supplementary figures, showing amino acid sequences, the PhoA activity of HrcR reporter fusions, and a multiple sequence alignment of $\mathrm{HrcV}$ homologues, are available with the online version of this paper. spp. and Xanthomonas spp. (Büttner \& Bonas, 2006; McCann \& Guttman, 2008). Moreover, several symbiotic bacteria also express T3S systems (Preston, 2007).

Nonflagellar T3S systems are encoded by 20-25 genes (Cornelis, 2006). Many structural components are conserved among pathogenic and symbiotic bacteria, and are strictly required to build up a functional secretion system. Nine components of the apparatus are conserved between nonflagellar T3S systems and the flagellar export apparatus (He et al., 2004; Nguyen et al., 2000). The broadly conserved proteins are believed to localize in the cytoplasm or constitute the inner ring structure of the secretion apparatus. Among them are six predicted integral inner membrane proteins forming the inner core of the T3S system, which probably acts as a secretion pore (Aizawa, 2001; Pühler et al., 2004; Tampakaki et al., 2004). The flagellar counterparts of five of them, FlhA, FlhB, FliP, FliQ and FliR, have been shown to constitute the flagellar export apparatus (Fan et al., 1997; Minamino \& Macnab, 2000b). The related nonflagellar T3S proteins also show manifold interactions with each other, thus suggesting similar multiprotein complexes for the flagellar and nonflagellar T3S systems (Creasey et al., 2003). This conclusion is supported by low-resolution electron microscopy, which demonstrates that the morphology of the nonflagellar T3S apparatus is remarkably similar to that of the flagellar 
hook-basal body complex (Kubori et al., 1998; Sekiya et al., 2001; Tamano et al., 2000). The main structural differences are found in the extracellular appendages. While nonflagellar T3S systems of animal pathogens are associated with a needle-like structure, plant pathogens possess a pilus-like structure on the surface, the Hrp pilus (Cornelis, 2006; He \& Jin, 2003).

Nonflagellar T3S has been studied best in Yersinia species, and the corresponding components are termed the lcr (low calcium response), ysc (Yop secretion) and yop (yersinial outer protein) genes (Cornelis, 2006). Nevertheless, structural information is still very limited, which holds particularly true for the six inner membrane components $\mathrm{YscV}, \mathrm{YscU}, \mathrm{YscT}, \mathrm{YscS}, \mathrm{YscR}$ and $\mathrm{YscD}$. The $\mathrm{YscV}$ (formerly LcrD) protein influences type III effector secretion and is related in sequence to the Salmonella inner membrane protein FlhA. Both YscV and FlhA are predicted to have seven transmembrane helices, with a cytoplasmic $\mathrm{N}$ terminus and a periplasmic $\mathrm{C}$ terminus (Melen et al., 2003). These predictions are in contrast to experimental data that support a cytoplasmic location of the C-terminal domain of FlhA and YscV (Minamino \& Macnab, 2000b; Plano et al., 1991). FlhA associates with FlhB (Zhu et al., 2002), which is related to the YscU protein. YscU, like FlhB, is thought to have four transmembrane helices followed by a cytoplasmic domain (Allaoui et al., 1994; Minamino et al., 1994). FlhB controls the substrate specificity and switches to the export of late structural subunits of the flagellum upon completion of early flagellar structures (Ferris \& Minamino, 2006; Fraser et al., 2003). This transition is accompanied by a proteolytic cleavage event in the C-terminal cytoplasmic domain of FlhB (Minamino \& Macnab, 2000a). YscU plays a similar role in the nonflagellar T3S system (Edqvist et al., 2003; Lavander et al., 2002). Proteolytic cleavage in the Cterminal cytoplasmic domain of YscU has been found to be necessary for Yop translocator secretion (Sorg et al., 2007). YscR, YscS and YscT are predicted to reside in the inner membrane with multiple transmembrane helices (Fields et al., 1994; Ghosh, 2004), and the flagellar counterparts, FliP, FliQ and FliR, have been experimentally identified in the inner membrane (Ohnishi et al., 1997). YscD has also been found in the inner membrane (Plano \& Straley, 1995), and shares a low level of sequence conservation with its homologues $\mathrm{PrgH}, \mathrm{MxiG}$ and $\mathrm{HrcD}$ (formerly HrpQ in $P$. syringae) (Ghosh, 2004; Pühler et al., 2004). The YscD/ HrpQ protein family (InterPro: IPR012843; http://www. ebi.ac.uk/interpro/IEntry?ac=IPR012843) is thought to form a multimeric ring, with each subunit being anchored in the inner membrane by one transmembrane helix (Moraes et al., 2008).

To date, only a few high-resolution structures of T3S components have been solved, mainly restricted to soluble proteins or extramembraneous domains of membrane proteins (Deane et al., 2008; Fadouloglou et al., 2004; Moraes et al., 2008; Zarivach et al., 2008). However, there is no high-resolution structural information available for any of the membrane-embedded protein domains, and knowledge about how they assemble into a multiprotein complex in the bacterial membrane is very limited. Because of the difficulties of deriving high-resolution models of membrane proteins, alternative strategies have been developed to obtain structural information at lower resolution, such as the position of transmembrane helices within the polypeptide chain and their orientation in the membrane (van Geest \& Lolkema, 2000).

In this study, we applied genetic tools to determine the membrane topology of the conserved inner membrane proteins of a T3S system, using the well-characterized plant pathogen Xanthomonas campestris pv. vesicatoria as a model (Gürlebeck et al., 2006).

In our laboratory, we study the causal agent of bacterial spot disease on pepper and tomato, X. campestris pv. vesicatoria, which causes important economic losses in growing regions with a warm and humid climate. It has therefore being recommended for regulation as a quarantine pest by the European and Mediterranean Plant Protection Organization (http://www.eppo.org/ QUARANTINE/listA2.htm). The interaction between $X$. campestris pv. vesicatoria and its host plants has been established as a model system for the molecular and genetic analysis of pathogenicity and plant resistance (Büttner \& Bonas, 2006; Gürlebeck et al., 2006). Basic pathogenicity is determined by a plant-inducible $23 \mathrm{~kb} h r p$ (hypersensitive reaction and pathogenicity) gene cluster which encodes a T3S system (Bonas et al., 1991; Weber et al., 2007). Most genes of the $h r p$ gene cluster are absolutely required for T3S in vitro as well as translocation of effector proteins into plant cells (Huguet et al., 1998; Rossier et al., 1999, 2000). Eleven $h r p$ genes which encode components of the T3S apparatus are also conserved in animal pathogens, and have been renamed $h r c$ genes ( $h r p$ conserved), using the same letter code as the archetypical $y s c$ homologue (Bogdanove et al., 1996; Pühler et al., 2004; Weber et al., 2005). The expression of the $h r p$ gene cluster is regulated by environmental signals and involves two regulatory proteins, HrpG and HrpX (Koebnik et al., 2006; Wengelnik \& Bonas, 1996; Wengelnik et al., 1996b). Extracellular key components of the $X$. campestris pv. vesicatoria T3S system are the Hrp pilus and the translocon, which together serve as a conduit for protein translocation from the bacterium into the plant host cell (Büttner et al., 2002; Weber et al., 2005). Recently, type III-specific chaperones and substrate specificity control proteins have been identified in our laboratory (Lorenz et al., 2008a, b). To gain novel insights into the molecular functionality of the T3S apparatus, we aimed at determining the membrane topology of all known inner membrane proteins. For this purpose, we performed a transposon mutagenesis leading to dual alkaline phosphatase- $\beta$-galactosidase (PhoA-LacZ $\alpha$ ) reporter fusions (Alexeyev \& Winkler, 2002). Enzymic and molecular characterization of the fusion proteins allowed us to derive at high resolution models of the membrane topology of $\mathrm{HrcD}, \mathrm{HrcR}, \mathrm{HrcS}, \mathrm{HrcT}, \mathrm{HrcU}$ and $\mathrm{HrcV}$. 


\section{METHODS}

Bacterial strains and growth conditions. E. coli cells were cultivated at $37{ }^{\circ} \mathrm{C}$ in lysogenic broth (LB) medium (Bertani, 1951). $X$. campestris pv. vesicatoria cells were cultivated at $28{ }^{\circ} \mathrm{C}$ in PSA medium ( $1 \%$ peptone, $1 \%$ sucrose, $0.1 \%$ glutamic acid). Since the wild-type $X$. campestris pv. vesicatoria strain $85-10$ produces large amounts of exopolysaccharides, the exopolysaccharide-negative strain 85E was used (Wengelnik et al., 1996a). Plasmids were introduced into E. coli TOP10 cells (Invitrogen) and into E. coli S17-1 (Simon et al., 1983) by electroporation. pBBR1-MCS5 constructs were transferred into $X$. campestris pv. vesicatoria strain $85 \mathrm{E}$ by biparental conjugation with E. coli S17-1 as donor.

Dual indicator plates for E. coli consisted of LB medium, $1.5 \%(\mathrm{w} / \mathrm{v})$ Bacto agar, $80 \mu \mathrm{g} \mathrm{ml}^{-1}$ 5-bromo-4-chloro-3-indolyl phosphate, disodium salt (X-phos; Carl Roth), $100 \mu \mathrm{g} \mathrm{ml}^{-1}$ 6-chloro-3-indolyl- $\beta$-Dgalactopyranoside (Rose-Gal; AppliChem), $80 \mathrm{mM} \mathrm{K}_{2} \mathrm{HPO}_{4}$, pH 7.0, and $0.2 \% \mathrm{~L}$-arabinose $(\mathrm{w} / \mathrm{v})$. Indicator plates for Xanthomonas consisted of PSA medium, $1.5 \%$ Bacto agar (w/v), $80 \mu \mathrm{g} \mathrm{X}$-phos $\mathrm{ml}^{-1}$ and $80 \mathrm{mM}$ $\mathrm{K}_{2} \mathrm{HPO}_{4}, \mathrm{pH}$ 7.0. Antibiotics were added to the media at the following final concentrations: $100 \mu \mathrm{g}$ ampicillin $\mathrm{ml}^{-1} ; 25 \mu \mathrm{g}$ kanamycin $\mathrm{ml}^{-1}$; $25 \mu \mathrm{g}$ gentamicin $\mathrm{ml}^{-1}$.

In vitro transposon mutagenesis. Coding sequences for $\mathrm{HrcD}$, $\mathrm{HrcR}, \mathrm{HrcS}$, HrcT, $\mathrm{HrcU}$ and $\mathrm{HrcV}$ were amplified by PCR from genomic DNA of X. campestris pv. vesicatoria strain 85-10 (Bonas et al., 1989; Thieme et al., 2005) using Pfu DNA polymerase (Stratagene), and cloned into pCR 2.1-TOPO (Invitrogen). For primer sequences, see Supplementary Table S1. Inserts with the correct DNA sequence were subcloned into pBAD24 (Guzman et al., 1995), which contains the $\mathrm{P}_{\mathrm{BAD}}$ promoter, the activity of which can be induced with $0.2 \%$ L-arabinose. For transposon mutagenesis, plasmid pMA814, which carries the mini-Tn5 transposon derivative Tnpholacl (Alexeyev \& Winkler, 2002), was used. Tnpholacl contains the dual phoA-lacZa reporter gene and a kanamycin-resistance gene, flanked by $19 \mathrm{bp}$ inverted repeats. When fused to an ORF, the PhoA-LacZ $\alpha$ reporter will be preceded by 13 amino acids (LSLIHISWPMGPG) in front of $\mathrm{Pro}_{6}$ of the mature PhoA protein.

In vitro transposition into pBAD derivatives containing $h r c$ genes was achieved using EZ::TN transposase (Epicentre Technologies). Equimolar amounts of the transposon donor plasmid (pMA814) and the target plasmid (pBAD24 derivative with the respective $h r c$ gene) were mixed with $1 \mu \mathrm{l}$ transposase in EZ::TN reaction buffer (final volume $10 \mu \mathrm{l}$ ). After $2 \mathrm{~h}$ at $37^{\circ} \mathrm{C}$, the reaction was stopped and the mixture transformed into E. coli TOP10 cells. Transformants were plated on dual indicator plates and grown for $24 \mathrm{~h}$ at $37^{\circ} \mathrm{C}$.

Mapping of Tnpholac1 insertions. Transposon insertion sites were mapped by colony PCR (Supplementary Table S1). Based on fragment size, plasmid DNA was isolated from representative clones using the QIAprep Spin Miniprep kit (Qiagen). The transposon insertion sites were sequenced using the BigDye terminator sequencing kit on an ABI Prism 310 Genetic Analyzer (Applied Biosystems).

Construction of site-specific reporter fusions. To obtain sitespecific reporter fusions, plasmid $\mathrm{pDT}$ was constructed. The PstI Tnpholacl fragment from pMA814 was cloned downstream of the $\mathrm{P}_{\mathrm{BAD}}$ promoter of pBAD24, and the resulting plasmid was digested with NotI and religated, thus removing the kanamycin-resistance gene and yielding plasmid pDT. The $h r c$ gene fragments of interest were amplified by PCR using gene-specific primers (Supplementary Table S1) and cloned in-frame in front of the phoA-lacZ $\alpha$ reporter using NheI and $\mathrm{XbaI}$. Expression resulted in chimeric proteins consisting of the Hrc fragment, a 20 amino acid linker (SRVDLQPLSLIHISWPMGPG), and the PhoA-LacZ $\alpha$ reporter starting at position $\mathrm{Pro}_{6}$ of the mature PhoA protein.
PhoA reporter assays in Xanthomonas. To perform reporter assays in $X$. campestris pv. vesicatoria, $h r c R$ reporter fusions were subcloned into a broad-host-range plasmid derived from pBBR1MCS5 (Kovach et al., 1995). BamHI-SacI fragments from pBAD reporter constructs were introduced into the pBBR1-MCS5 derivative downstream of a modified $h r p X$ gene (A. Krüger and R. Koebnik, unpublished results), thus forming an operon fusion. This plasmid led to expression of a double-tagged HrpX protein from $X$. campestris pv. vesicatoria strain $85-10$, with an N-terminal hexahistidine tag and a C-terminal Strep-tag II (IBA BioTAGnology). Upon conjugation into $X$. campestris pv. vesicatoria strain $85 \mathrm{E}$, clones were selected on kanamycin/gentamicin plates and subsequently streaked on indicator plates. After 5 days of cultivation, bacteria were resuspended in $5 \mathrm{ml}$ sterile water and assayed for coloration.

Bioinformatics predictions. Common algorithms were used for membrane topology predictions, using default parameters: TopPred II (http://bioweb.pasteur.fr/seqanal/interfaces/toppred.html) (von Heijne, 1992), TMHMM version 2.0 (http:/www.cbs.dtu.dk/services/ TMHMM-2.0/) (Krogh et al., 2001), HMMTOP version 2.0 (http:/ www.enzim.hu/hmmtop/) (Tusnady \& Simon, 2001), MEMSAT version 3 (http://bioinf.cs.ucl.ac.uk/psipred/) (Jones, 2007), PHDhtm (http://www.predictprotein.org/) (Rost et al., 2004) and Phobius (http://phobius.cgb.ki.se/) (Käll et al., 2004).

\section{RESULTS AND DISCUSSION}

\section{Bioinformatics prediction of the membrane topology of six Hrc proteins}

Several algorithms are available to predict the topology of membrane proteins (Elofsson \& von Heijne, 2007). Since combined predictions are more reliable than single predictions (Ikeda et al., 2002; Nilsson et al., 2000), we applied six internet-based algorithms (TopPred, TMHMM, HMMTOP, MEMSAT, PHDhtm and Phobius) (Fig. 1) to predict the membrane topology of the predicted inner membrane proteins $\mathrm{HrcD}$, HrcR, $\mathrm{HrcS}, \mathrm{HrcT}, \mathrm{HrcU}$ and $\mathrm{HrcV}$ from the $X$. campestris pv. vesicatoria T3S system. In no case did the six algorithms predict the same number of transmembrane segments (TMSs). Similarly, for most extramembraneous regions, different locations, i.e. in the cytoplasm or periplasm, were predicted. Also, the hidden Markov model-based algorithms TMHMM, HMMTOP and Phobius differed in their predictions. TMHMM was less sensitive: it did not predict any TMS in $\mathrm{HrcD}$, missed TMS I of HrcU and the predicted TMS II of HrcT, and failed to predict two TMSs instead of only one at about amino acid residues 280-320 of HcrV. Surprisingly, TMHMM and HMMTOP often predicted opposite orientations of the protein within the membrane $(\mathrm{HrcD}$, $\mathrm{HrcS}$, most of HrcT and $\mathrm{HrcU}$, and the C-terminal soluble domain of $\mathrm{HrcV}$ ). Phobius, which has been designed to differentiate between TMSs and signal sequences of the general secretion pathway, predicted a signal sequence instead of a TMS at the N-terminal regions of $\mathrm{HrCD}$ and HrcR. Hence, from predictions, it remained unclear whether or not the $\mathrm{N}$-terminal region is processed by the leader peptidase. PHDhtm, a two-layer neural network, tended to predict shorter TMSs than the other algorithms, 
$\begin{array}{llllllllllll}H r c D & (221 \\ \text { aa) } & 20 & 40 & 60 & 80 & 100 & 120 & 140 & 160 & 180 & 200 & 220\end{array}$

EXP.

TopPred

TMHMM

HMMTOP

MEMSAT

PHDhtm

Phobius

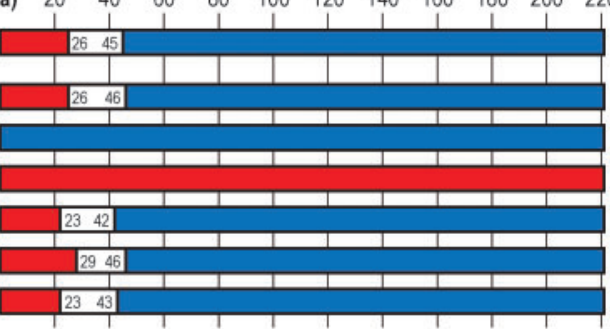

$\begin{array}{llllllllllllll}\text { HrcT (276 aa) } & 20 & 40 & 60 & 80 & 100 & 120 & 140 & 160 & 180 & 200 & 220 & 240 & 260\end{array}$

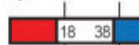

TopPred \#1 $\square\left[\begin{array}{ll}18 & 36 \\ \hline\end{array}\right.$

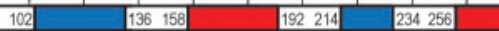

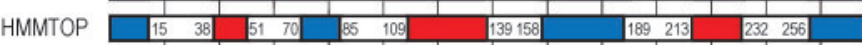

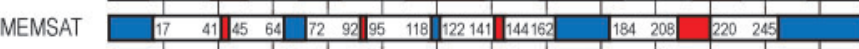

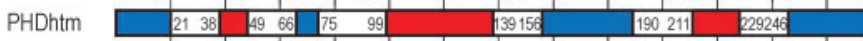

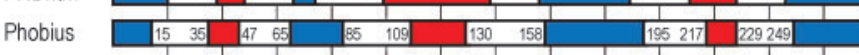

$\begin{array}{lllllllllll}\text { HrcR (214 aa) } & 20 & 40 & 60 & 80 & 100 & 120 & 140 & 160 & 180 & 200\end{array}$

EXP.

TopPred

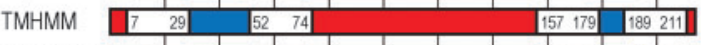

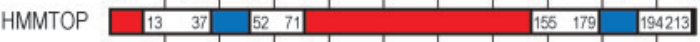

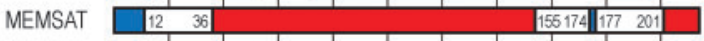

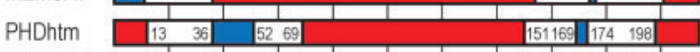

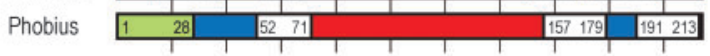

HrcS (86 aa) $\quad 20 \quad 40 \quad 60 \quad 80$

EXP.

TopPred

TMHMM

HMMTOP

MEMSAT

PHDhtm

Phobius

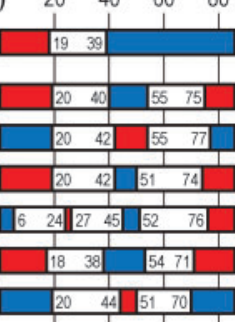

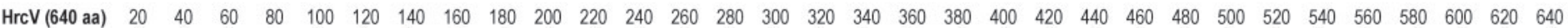

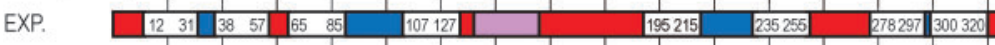

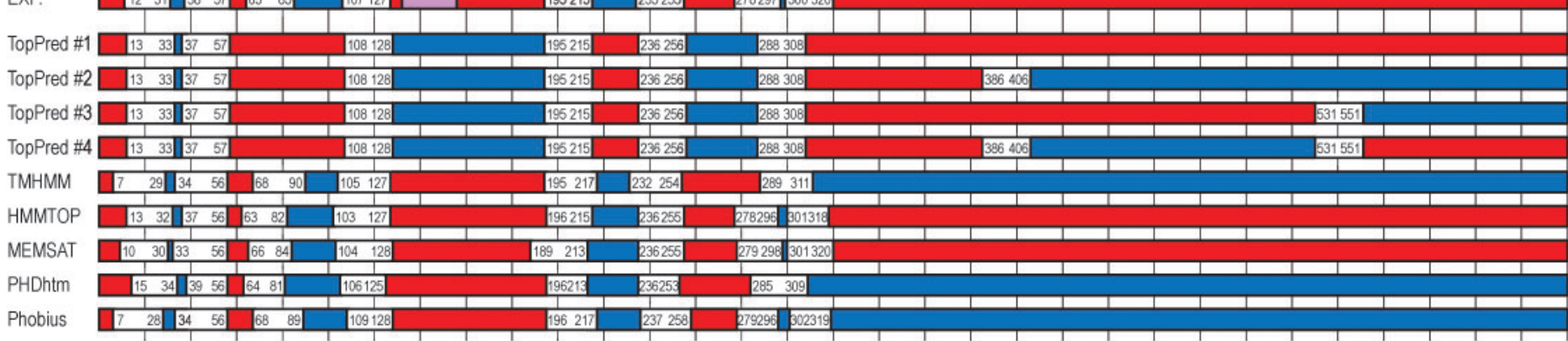

Fig. 1. Bioinformatics predictions and experimentally derived membrane topology of conserved inner membrane proteins of the $X$. campestris pv. vesicatoria T3S system. Six algorithms were applied to predict the membrane topology of $\mathrm{HrcD}$, HrcR, HrcS, HrcT, HrcU and HrcV. For HrcT and HrcV, TopPred predicted two and four different models, respectively. For comparison, the experimentally derived topology models (EXP.) are shown at the top. Transmembrane segments are shown in white, periplasmic regions in blue and cytoplasmic regions in red. Predicted signal sequences are indicated in green. The cytoplasmic NPTH motif of HrcU, corresponding to the strictly conserved cleavage site within the YscU/FIhB protein family, is indicated in yellow. The cytoplasmic FHIPEP motif of HrcV is indicated in purple. 
probably due to the second layer which aims at correcting for too-long TMS lengths. MEMSAT, which uses multiple sequence alignments to recognize topology models by expectation maximization, tended to predict two short TMSs instead of one long TMS for extended regions of high hydrophobicity (two TMSs for TMS I of HrcS and two extra TMSs for HrcT). In summary, no unambiguous topology model was predicted for any of the six selected Hrc proteins.

\section{Isolation of reporter fusions to inner membrane Hrc proteins}

Because of the difficulties of obtaining reliable topology predictions we studied the membrane topology of six Hrc proteins by reporter fusions, using Tnpholacl-based mutagenesis in E. coli (Alexeyev \& Winkler, 2002). The simultaneous use of two reporter enzymes, alkaline phosphatase (PhoA) and $\beta$-galactosidase (LacZ), allows enzymic readouts for both periplasmic and cytoplasmic localization at each fusion point.

Coding sequences for the six predicted inner membrane proteins $\mathrm{HrcD}, \mathrm{HrcR}, \mathrm{HrcS}, \mathrm{HrcT}, \mathrm{HrcU}$ and $\mathrm{HrcV}$ from $X$. campestris pv. vesicatoria were cloned under the control of an arabinose-inducible $\mathrm{P}_{\mathrm{BAD}}$ promoter and mutagenized by Tnpholac1 in vitro. After selection on plates containing the chromogenic substrates X-Phos and Rose-Gal, four types of colonies were obtained. Blue colonies, indicating PhoA activity, correspond to hybrid proteins with a fusion site in or close to a periplasmic region of the Hrc protein. Red colonies were due to LacZ activity and suggested a fusion in or close to a cytoplasmic domain. White colonies, which were obtained predominantly, were likely due to out-of-frame fusions of the reporter genes with the hrc gene, to have an insertion of the reporters in the opposite direction to the hrc gene, or to harbour the reporters somewhere else in the mutagenized plasmid. Occasionally, purple colonies were observed. In these cases, the fusion point might be located within a TMS, thus allowing only some but not all reporter moieties to be translocated to the periplasm (Alexeyev \& Winkler, 2002). Preliminary studies had shown that out-of-frame fusions tended to display an erratic behaviour, probably due to translation reinitiation in the vicinity of $l a c Z \alpha$. Therefore, we only analysed colonies with intense coloration.

Generally, many different, randomly distributed fusion points were obtained for the six Hrc proteins, thus allowing us to build precise topology models. In all, we selected nine different translationally in-frame Tnpholacl fusions in $h r c D, 26$ in $h r c R$, nine in $h r c S, 25$ in $h r c T, 21$ in $h r c U$ and 32 in $h r c V$ (Fig. 2), and labelled them with the number of the amino acid residue after which the fusion occurred. To close gaps in regions where no fusions were obtained, site-specific fusions were constructed, i.e. after positions $\mathrm{S}_{50}, \mathrm{~L}_{80}$ and $\mathrm{P}_{86}$ in $\mathrm{HrcS}$, after positions $\mathrm{Q}_{119}, \mathrm{~S}_{223}$ and $\mathrm{I}_{229}$ in $\mathrm{HrcT}$, and after position $\mathrm{S}_{134}$ in $\mathrm{HrcU}$ (see Methods).

\section{Model building}

For model building, we took advantage of the bioinformatics prediction of candidate TMSs (Fig. 1). We considered all potential TMSs which were predicted by at least one algorithm. However, predictions of pairs of TMSs which corresponded to only one experimentally supported TMS (TMS I and TMS II of HrcS, and TMS III-VI of HrcT, as predicted by MEMSAT) were not considered. When several algorithms predicted a TMS, we defined those amino acid residues as the core of the TMS that were predicted by all algorithms (Supplementary Fig. S1). Since the core sizes varied between five and 20 amino acids, we normalized all TMSs to a reasonable length of 20 or 21 residues necessary to span the lipid bilayer by adding equal numbers of amino acids to both sides of the core. TMSs are counted from the $\mathrm{N}$ to the $\mathrm{C}$ terminus of the protein by roman numbers: TMS I, TMS II, etc.

The theoretical topology models were then compared with our experimental data which localized the hydrophilic stretches of the polypeptide chain either in the cytoplasm or in the periplasm. Predicted TMSs were not considered when the enzymic activities of fusions at both sides of a predicted TMS did not support their existence. Often, fusions with LacZ or PhoA activity were found too close to each other to be separated by a complete TMS, suggesting that the fusion sites were located within the TMS. This finding was not surprising, since it has been demonstrated before that an incomplete TMS in $\mathrm{N}_{\text {in }}-\mathrm{C}_{\text {out }}$ orientation can be sufficient to transport a downstream protein segment across the membrane (Boyd et al., 1987; Calamia \& Manoil, 1990; Pourcher et al., 1996; Ujwal et al., 1995). This is probably especially true in our experimental system, in which the reporter fusion adds a short stretch of amino acids with elevated hydrophobicity (LSLIHI) due to the inverted repeat of the mini transposon (see Methods). Hence, fusions within the $\mathrm{N}$-terminal third of an $\mathrm{N}_{\mathrm{in}}-\mathrm{C}_{\text {out }}$ TMS are expected to have LacZ activity, while fusions in the C-terminal two-thirds can lead to PhoA activity. Analogously, fusions within or at the C-terminal end of an $\mathrm{N}_{\text {out }}-\mathrm{C}_{\text {in }}$ TMS often have PhoA activity. This is probably due to missing downstream topogenic information, which holds the reporter moiety back in the cytoplasm (van Geest \& Lolkema, 2000). In these cases, we therefore scrutinized the sequence context for the presence of topogenic signals, i.e. positively charged amino acids (von Heijne, 1986).

\section{HrcD contains a single $\mathrm{N}$-terminal transmembrane helix followed by a periplasmic protein domain}

We first studied the 221 amino acid $\mathrm{HrcD}$ protein (formerly HrpD5) (Fig. 2 and Supplementary Fig. S1), which originally was predicted to have 312 amino acids when we started the project (Huguet et al., 1998). Later we found that the formerly predicted start codon was located upstream of the transcriptional start site, as determined by rapid amplification of $5^{\prime}$ complementary DNA ends (5'RACE) experiments (Weber et al., 2007). As a con- 

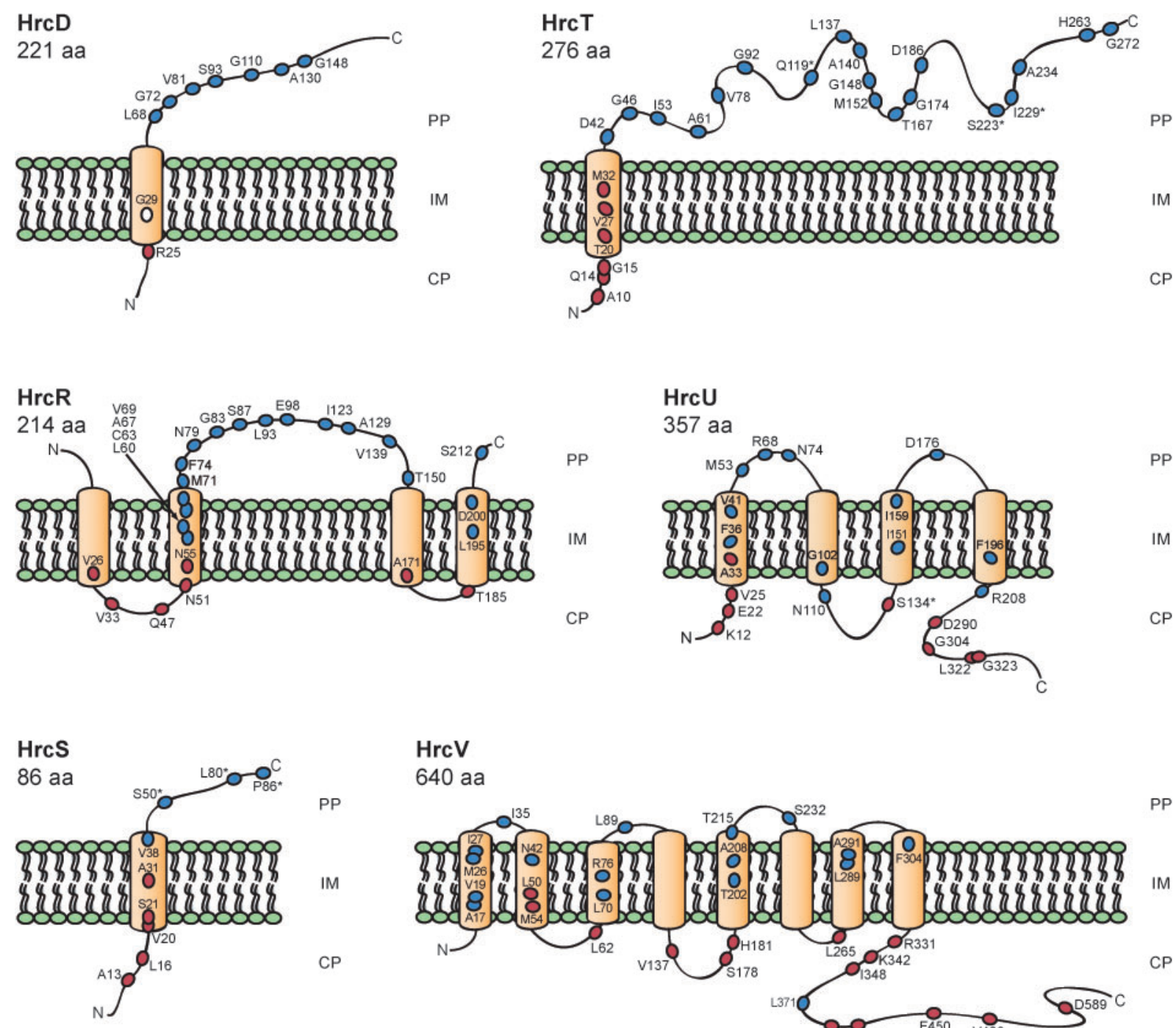

HrcV
640 aa

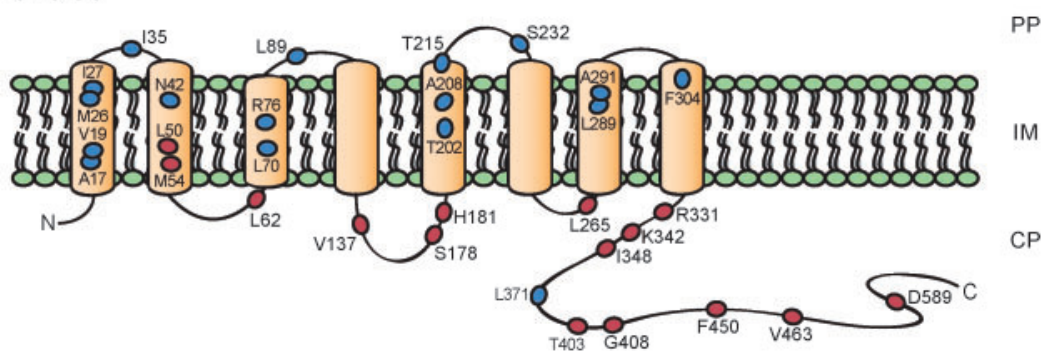

Fig. 2. Models of the membrane topology of HrcD, HrcR, HrcS, HrcT, HrcU and HrcV. Phenotypes of phoA-lacZ $\alpha$ reporter fusions are indicated by blue (PhoA activity) and red (LacZ activity) ellipses, along with the amino acid position at which the reporters were fused. For HrcD, a purple colony was observed, indicating the activity of both enzymes (white ellipse; see text). $\mathrm{PP}$, periplasm; IM, inner membrane; $\mathrm{CP}$, cytoplasm. Orange cylinders represent transmembrane segments. Asterisks indicate fusions in $\operatorname{HrcS}\left(\mathrm{S}_{50}, \mathrm{~L}_{80}, \mathrm{~L}_{86}\right)$, $\operatorname{HrcT}\left(\mathrm{Q}_{119}, \mathrm{~S}_{223}, \mathrm{I}_{229}\right)$ and $\mathrm{HrcU}\left(\mathrm{S}_{134}\right)$ which were obtained by site-directed mutagenesis.

sequence, a new translational start codon was defined for $h r c D$ that is located 91 codons downstream of the previously predicted start site. The new start codon is preceded by a possible Shine-Dalgarno sequence and would result in a $24 \mathrm{kDa}$ protein. Support for this prediction comes from the expression of a C-terminally hexahistidine-tagged $\mathrm{HrcD}$ in X. campestris pv. vesicatoria, which allows the purification of a $25 \mathrm{kDa}$ protein (Weber et al., 2007). However, probably due to N-terminal modification of the protein, the $\mathrm{N}$-terminal amino acid sequence could not be determined (C. Berger \& R. Koebnik, unpublished results). Based on the first prediction, we have used the 312 codon sequence of $h r c D$ for plasmid construction and transposon mutagenesis. Since in this case the first 91 codons do not contain any stretch of hydrophobic amino acids sufficient to span the lipid bilayer, all conclusions from the longer sequence are also valid for the shorter one. Indeed, we had obtained six fusions within the first 91 codons which all led to red colonies, indicating the absence of a putative TMS in this region (data not shown). Therefore, we will refer to the refined numbering throughout this work.

We selected nine different in-frame hrcD::Tnpholac1 mutants, one red, one purple and seven blue colonies (Fig. 2). The red colony had a fusion after position $R_{25}$, indicating that the $\mathrm{N}$ terminus of $\mathrm{HrcD}$ is located in the cytoplasm. For the purple colony, the fusion site was found 
after position $G_{29}$, which overlaps with a hydrophobic segment centred at position $\mathrm{A}_{35}$ (Supplementary Fig. S1), indicative of a location within a TMS. All fusions downstream of amino acid $\mathrm{L}_{68}$ resulted in blue colonies, suggesting the absence of an additional TMS in this region and a periplasmic location of the C-terminal protein domain. Our results are supported by four predictions, TopPred, MEMSAT, PHDhtm and Phobius (Fig. 1). Only two hidden Markov model-based algorithms, TMHMM and HMMTOP, predicted a soluble protein without any TMS in the 221 amino acid protein.

$\mathrm{HrcD}$ is similar ( $30 \%$ sequence identity) to $\mathrm{HrpW}$ of $R$. solanacearum (323 amino acids; accession no. CAD18008), and weakly related to HrpQ of P. syringae (330 amino acids; AAO54923), YscD of Yersinia (419 amino acids; AAC62551), PrgH of Salmonella (392 amino acids; AAB60188) and MxiG of Shigella (371 amino acids; CAC05811) (Ghosh, 2004; Huguet et al., 1998; Pühler et al., 2004; Van Gijsegem et al., 2002). Since $\mathrm{PrgH}$ is a component of the needle complex, the cell-surface appendage of the T3S system of animal pathogens (Galan \& Wolf-Watz, 2006; Kubori et al., 1998), HrcD might play a role in the assembly of the Hrp pilus, the appendage of plant pathogens. Such a role is supported by the cotranscription of $h r c D$ with two other genes devoted to Hrp pilus assembly, $h r p D 6$ and $h r p E$, the latter encoding the major pilus subunit (Weber et al., 2005, 2007). Some members of the YscD/HrpQ protein family contain a (cytoplasmic) FHA (forkhead-associated) domain at the $\mathrm{N}$ terminus. The FHA domain is a phosphopeptide recognition domain found in many regulatory proteins, e.g. kinases and phosphatases (Durocher \& Jackson, 2002). $\mathrm{HrcD}$ is significantly shorter at the $\mathrm{N}$ terminus and lacks the FHA domain. This finding is not surprising because the FHA domains of YscD-like proteins might just represent a molecular fossil which is undergoing evolutionary erosion (Pallen et al., 2005).

\section{HrcR is a four-transmembrane-helix protein with a central periplasmic domain}

For $h r c R$, we selected seven red and 18 blue Tnpholac1 mutants (Fig. 2 and Supplementary Fig. S1). All fusions upstream of position $\mathrm{G}_{56}$ resulted in red colonies, suggesting a cytoplasmic location of this region. Since all six algorithms predict a hydrophobic, membrane-interacting segment within the first 37 amino acid residues (Fig. 1), we are confident about the presence of an $\mathrm{N}_{\text {out }}-\mathrm{C}_{\text {in }}$ TMS (TMS I) in this region, for which, however, experimental proof cannot be obtained by our approach. The Phobius algorithm suggested that the candidate TMS I is a signal sequence which is removed by the leader peptidase. If this is the case, one would expect that fusions immediately downstream of the processing site would lead to PhoA activity. However, fusions after $\mathrm{V}_{26}$ and $\mathrm{V}_{33}$ resulted in red colonies. Moreover, bioinformatics analyses (Phobius) of 20 randomly chosen HrcR homologues with less than $85 \%$ pairwise identity, including YscR from Yersinia pestis, did not predict a classical signal sequence for any of them (data not shown). Thus, the N-terminal hydrophobic segment likely corresponds to a TMS and not to a signal sequence.

The most N-terminal fusion leading to a blue colony was obtained after position $\mathrm{L}_{60}$, in agreement with a model placing this fusion site in TMS II $\left(\mathrm{N}_{\mathrm{in}}-\mathrm{C}_{\text {out }}\right)$. A periplasmic loop of approximately 80 amino acid residues between TMS II and TMS III, from $\mathrm{M}_{71}$ to $\mathrm{A}_{152}$, is supported by more than 10 insertions resulting in blue colonies. Two fusions at $\mathrm{A}_{171}$ and $\mathrm{T}_{185}$, leading to red colonies, support the existence of TMS III in the C-terminal half of the protein, and three fusions with a blue phenotype after positions $\mathrm{L}_{195}, \mathrm{D}_{200}$ and $\mathrm{S}_{212}$ clearly localize the C-terminal region in the periplasmic space. Hence, the polypeptide chain of HrcR traverses the inner membrane by four transmembrane helices.

Five of six algorithms predicted an opposite orientation of the protein in the membrane and only TopPred supports our model of HrcR. This situation is reminiscent of topology studies with the HrcR homologue from Y. pestis, YscR. Based on six TnphoA fusions, of which only one fusion at amino acid residue 45 gave rise to high PhoA activity, Fields et al. (1994) proposed four TMSs for YscR, with both protein termini residing in the cytoplasm. Thus, there are two alternative models for members of the YscR/ HrcR protein family with opposite orientation in the membrane, a situation that is not without precedent (von Heijne, 2006). Still, this finding is surprising, since HrcR and YscR share $50 \%$ sequence identity. Because of the high density of transposon insertions in $h r c R$ and the double enzymic readout for all the fusion proteins we are confident that our HrcR model is correct. Our model is also supported by two PhoA fusions in the central loop of HrcR (formerly HrpT) from $R$. solanacearum (Van Gijsegem et al., 1995), corresponding to positions $S_{84}$ and $\mathrm{V}_{90}$ of HrcR from X. campestris pv. vesicatoria.

To exclude any artefacts that might originate from the use of $E$. coli, we transferred six representative $\mathrm{HrcR}$ fusions into $X$. campestris pv. vesicatoria. Reporter fusions were cloned into a broad-host-range plasmid downstream of a constitutively expressed $h r p X$ derivative. This plasmid complemented an $h r p X$ mutant and activated the expression of $h r p X$-dependent $h r p$ operons (A. Krüger, G. P. Robin and R. Koebnik, unpublished results). On indicator plates for PhoA activity, we observed bluish colonies with fusions after positions $\mathrm{N}_{79}, \mathrm{E}_{98}$ and $\mathrm{T}_{150}$ (Supplementary Fig. S2). In contrast, fusions after positions $N_{51}, A_{171}$ and $\mathrm{T}_{185}$ led to the same greenish colonies as the strain with the 'empty' hrpX plasmid, most likely due to low background activity of the endogenous phoA gene and the yellow pigment xanthomonadin (Supplementary Fig. S2). Since xanthomonads expressing the $\operatorname{Lac} Z \Omega$ fragment in a strain without endogenous $\beta$-galactosidase are not available, we could not determine the LacZ activity of the reporter fusions. In summary, we observed the same topology in $E$. 
coli and in X. campestris pv. vesicatoria regardless of the presence or absence of other Hrc proteins, including the $\mathrm{HrcJ} / \mathrm{HrcD}$ ring as a molecular platform for T3S apparatus assembly (Yip et al., 2005; Spreter et al., 2009).

\section{HrcS has at least one transmembrane helix and a periplasmic $\mathbf{C}$ terminus}

HrcS, with only 86 amino acids, is the smallest inner membrane Hrc protein. The topology model for $\mathrm{HrcS}$ derived from nine transposon insertions shows only one TMS (Fig. 2 and Supplementary Fig. S1). The insertions $A_{13}, L_{16}, V_{20}$ and $S_{21}$ had LacZ activity, thus being compatible with a cytoplasmic location of the $\mathrm{N}$ terminus. Although insertions $A_{31}$ and $V_{38}$ lie close together, they led to LacZ and PhoA activity, respectively. The two amino acid residues are separated by a hydrophobic stretch (GLLIAF), and are thus probably located in the N- and Cterminal halves of a TMS. Three additional fusions after positions $\mathrm{S}_{50}, \mathrm{~L}_{80}$ and $\mathrm{P}_{86}$ in $\mathrm{HrcS}$ were constructed in pDT and resulted in high PhoA activity. The same phenotype has been observed with PhoA fusions after position $S_{50}$ of $\mathrm{HrcS}$ (formerly HrpU) of $R$. solanacearum (Van Gijsegem et al., 1995), corresponding to position $S_{50}$ of $\mathrm{HrcS}$ from $X$. campestris pv. vesicatoria. In contrast to the experimental data, all algorithms predicted two or three TMSs with different orientations in the membrane (Fig. 1). Only the $\mathrm{N}$-terminally located predicted TMS fits well to our data because experimental support for the existence of a second (or third) TMS in the C-terminal part of the protein is missing. However, we cannot entirely rule out the possibility that the $\mathrm{N}$-terminal TMS (in $\mathrm{N}_{\text {in }}-\mathrm{C}_{\text {out }}$ orientation) exports the reporter in the $V_{38}$ and $S_{50}$ fusions, leading to PhoA activity. But when more amino acid residues of $\mathrm{HrcS}$ are present in the fusion protein, the $\mathrm{N}$ terminal TMS might adopt the opposite orientation $\left(\mathrm{N}_{\text {out }}{ }^{-}\right.$ $\left.\mathrm{C}_{\text {in }}\right)$ and a second TMS $\left(\mathrm{N}_{\mathrm{in}}-\mathrm{C}_{\text {out }}\right)$ might be formed. This scenario would be compatible with the predictions of TMHMM and Phobius. In any case, the $\mathrm{C}$ terminus of $\mathrm{HrcS}$ is located on the periplasmic side, as suggested by the two fusions after positions $\mathrm{L}_{80}$ and $\mathrm{P}_{86}$.

\section{HrcT contains an $\mathbf{N}$-terminal transmembrane anchor followed by a large periplasmic domain}

Our experimental data suggest that the 276 amino acid HrcT protein is an integral membrane protein with only one TMS close to the $\mathrm{N}$ terminus which serves as a membrane anchor (Fig. 2 and Supplementary Fig. S1). This conclusion is based on 25 PhoA-LacZ $\alpha$ fusions. All six fusions before amino acid $\mathrm{F}_{33}$ resulted in high LacZ activity, while all 19 fusions behind amino acid $\mathrm{D}_{42}$ resulted in high PhoA activity. Because we did not isolate any Tnpholac1-based fusion between positions $\mathrm{G}_{92}$ and $\mathrm{L}_{137}$ and between positions $\mathrm{D}_{186}$ and $\mathrm{A}_{234}$, we constructed three additional site-specific fusions after positions $\mathrm{Q}_{119}, \mathrm{~S}_{223}$ and $\mathrm{I}_{229}$. Since these constructs also resulted in high PhoA activity we conclude that HrcT contains a large periplasmic domain, starting at approximately amino acid $T_{39}$ (Supplementary Fig. S1).

Surprisingly, this model is in sharp contrast to bioinformatics predictions, which consistently predicted five to eight TMSs for HrcT (Fig. 1). The $\mathrm{N}$ terminus is predicted, except for one of the two TopPred models, to be in the periplasm. Since we considered all the rules of van Geest and Lolkema, i.e. a minimum of one fusion in each predicted extra-membraneous domain and at least one fusion for every 30 amino acid residues in regions of intermediate hydrophobicity (van Geest \& Lolkema, 2000), and obtained a positive readout (i.e. high PhoA activity) for all fusions downstream of position $\mathrm{D}_{42}$, we believe that HrcT contains a large C-terminal periplasmic domain.

\section{Hrc U has an $\mathbf{N}$-terminal membrane-embedded domain and a C-terminal cytoplasmic domain}

For the 357 amino acid $\mathrm{HrcU}$ protein, we isolated 21 different PhoA-LacZ $\alpha$ fusions (Fig. 2 and Supplementary Fig. S1). Fusions with PhoA activity were restricted to the $\mathrm{N}$-terminal 210 amino acid residues, indicative of a membrane-embedded domain in the $\mathrm{N}$-terminal protein region. Our data are in agreement with four TMSs in this region, as predicted by all algorithms except TMHMM, which did not predict the first TMS. The insertions $\mathrm{A}_{33}$ and $\mathrm{F}_{36}$, resulting in red and blue colonies, respectively, are probably both located in the first TMS. Insertions $\mathrm{N}_{110}$ and $\mathrm{R}_{208}$, although leading to PhoA activity, are probably located on the cytoplasmic side of the membrane close to the C-terminal end of an $\mathrm{N}_{\text {out }}-\mathrm{C}_{\text {in }}$ TMS (Fig. 1). Scrutiny of the amino acid sequence context revealed that both residues are followed by two or three basic amino acids within the next 10 residues, which might have a topogenic function (Supplementary Fig. S1) (von Heijne, 1986). From this we conclude that missing downstream topogenic information is responsible for this atypical, but not unexpected, behaviour (van Geest \& Lolkema, 2000). Because Tnpholacl mutagenesis did not lead to fusions supportive of TMS II and TMS III, we constructed a sitespecific fusion after position $S_{134}$. As expected, this fusion resulted in high LacZ activity, thus confirming the fourTMS model for the $\mathrm{N}$-terminal 205 amino acid residues.

All four reporter fusions downstream of amino acid $\mathrm{R}_{208}$ gave rise to high PhoA activity, indicative of a large cytoplasmic protein domain (Fig. 2 and Supplementary Fig. S1). Our model of $\mathrm{HrcU}$ is corroborated by a model of YscU from Yersinia enterocolitica which is based on 10 PhoA fusions (Allaoui et al., 1994). Thus, both proteins share a large C-terminal cytoplasmic domain with a conserved proteolytic cleavage site which plays a role in substrate specificity switching (Lavander et al., 2002; Minamino \& Macnab, 2000a). HrcU cleavage has been observed by immunoblot analysis, suggesting a similar but distinct mechanism of substrate specificity control (C. Berger \& R. Koebnik, unpublished results; Lorenz et al., 2008b). 


\section{HrcV is a two-domain membrane protein with a large cytoplasmic domain in the $\mathrm{C}$-terminal region}

For $h r c V$, we selected 15 red and 17 blue Tnpholacl mutants (Fig. 2 and Supplementary Fig. S1). Within the N-terminal half of the 640 amino acid $\mathrm{HrcV}$ protein we observed clusters of reporter fusions with either LacZ or PhoA activity along the polypeptide chain, indicative of a large membraneembedded domain. These data are in agreement with the presence of eight TMSs (TMS I to TMS VIII), as predicted by most algorithms (Fig. 1 and Supplementary Fig. S1). According to the positive-inside rule and the presence of two positively charged amino acids $\left(R_{2}\right.$ and $\left.R_{5}\right)$, the $\mathrm{N}$ terminus was expected to reside in the cytoplasm. This was also predicted by all six algorithms (Fig. 1). Not unexpectedly, several fusions within the $\mathrm{N}$-terminal half of an $\mathrm{N}_{\mathrm{in}}-\mathrm{C}_{\text {out }}$ TMS (i.e. after positions $A_{17}, V_{19}, L_{70}$ and $T_{202}$ ) showed PhoA activity. Our model places the diagnostic FHIPEP motif (PROSITE accession no. PS00994) into the second cytoplasmic loop between TMS IV and TMS V, as proposed for FlhA (Fig. 1) (McMurry et al., 2004).

Except for one fusion ( $\mathrm{L}_{371}$, see below), all fusions downstream of amino acid $\mathrm{R}_{331}$ in $\mathrm{HrcV}$ led to $\mathrm{LacZ}$ activity, suggesting that $\mathrm{HrcV}$ possesses a large $\mathrm{C}$-terminal cytoplasmic domain of approximately 320 amino acids. The localization of this domain varied in the predictions (Fig. 1). A C-terminal TMS at amino acid positions 531551, which was predicted only by TopPred, is unlikely because the downstream reporter fusion after position $\mathrm{D}_{589}$ led to LacZ activity. Moreover, the corresponding region of the flagellar homologue, FlhA, has been purified and crystallized without detergent, supporting a soluble protein domain (Saijo-Hamano et al., 2004, 2005). A cytoplasmic location of the C-terminal domain of the YscV/FlhA protein family is also supported by the finding that the Cterminal domain of FlhA interacts with the cytoplasmic proteins FliJ, FliH and FliI (Minamino \& Macnab, 2000b). Moreover, FlhA has been shown to interact with the Cterminal domain of FlhB, the HrcU homologue (Zhu et al., 2002). Similar findings have been obtained in our laboratory using a bacterial two-hybrid system (Dmitrova et al., 1998), showing that the soluble domain of $\mathrm{HrcV}$ $\left(\mathrm{HrCV}_{322-645}\right)$ interacts with itself and with the soluble domain of $\mathrm{HrcU}\left(\mathrm{HrcU}_{265-357}\right)$ (C. Berger \& R. Koebnik, unpublished results). Thus, the large C-terminal domain of $\mathrm{HrcV}$ is localized in the cytoplasm.

The reporter fusion after position $\mathrm{L}_{371}$, which led to PhoA activity, is of special interest. To include this particular fusion into the model, an upstream $\mathrm{N}_{\text {in }}-\mathrm{C}_{\text {out }}$ TMS (TMS IX) would have to be postulated. We believe that the fairly hydrophobic sequence $\mathrm{L}_{359} \mathrm{SMRLSPQLAALL}_{371}$, which is just upstream of the $\mathrm{L}_{371}$ fusion point, has the potential to form a TMS when fused to a few additional hydrophobic amino acids (LSLIHI) derived from the PhoA-LacZ $\alpha$ reporter (Supplementary Fig. S1). Hence, an artificial TMS might be formed upon fusion after $\mathrm{L}_{371}$, leading to the export of the reporter, and the presumed TMS IX is likely absent in the wild-type protein. In support of this, a comparison of $\mathrm{HrcV}$ homologues from 14 different genera shows that a fairly hydrophobic sequence is not conserved in this region of the polypeptide chain (Supplementary Fig. S3). Thus, the fusion after position $\mathrm{L}_{371}$ most likely led to an experimental artefact and illustrates the importance of careful analysis of all the fusion constructs.

The $\mathrm{HrcV}$ homologue from $Y$. pestis, YscV (formerly LcrD), has been studied by TnphoA mutagenesis, leading to a model of YscV with eight TMSs and a large cytoplasmic C-terminal domain (Plano et al., 1991). The last TMS of YscV, TMS VIII, is predicted between amino acids 330 and 347; however, this region is fairly hydrophilic and not likely to form a TMS. We therefore suggest that TMS VIII resides between positions $\mathrm{F}_{301}$ and $\mathrm{L}_{320}$ in $\mathrm{YscV}$, which corresponds to positions $\mathrm{F}_{299}$ and $\mathrm{I}_{318}$ in $\mathrm{HrcV}$ (TMS VIII). This model would explain the PhoA activity of $\mathrm{YscV}$ fusions $\mathrm{L}_{297}$ and $\mathrm{V}_{304}$ (Plano et al., 1991). The PhoA activity of two fusions at the C-terminal end of TMS VIII $\left(\mathrm{G}_{317}\right.$ and $\mathrm{L}_{320}$ of $\mathrm{YscV}$ ) could be explained by the lack of downstream topogenic information, i.e. the conserved Arg-Lys motif at amino acid residues 322 and 323 (van Geest \& Lolkema, 2000).

\section{Validity of the PhoA-LacZ reporter fusion approach to study the membrane topology of inner membrane proteins}

Our experimental approach relied on the assumption that inner membrane proteins can be studied individually upon heterologous expression in E. coli although they are normally part of a multiprotein complex, i.e. the T3S apparatus. The validity of the gene fusion approach for a heterologous protein of a multiprotein complex has been demonstrated for the L-subunit of the photosynthetic reaction centre from Rhodobacter sphaeroides (Yun et al., 1991). Gene fusions with high PhoA activity were shown to be in regions of the polypeptide known to be at or near the periplasmic surface, as defined by the high-resolution X-ray structure. Later, several proteins of heterologous multiprotein complexes have been studied by reporter fusions expressed in E. coli, e.g. the pro-sigma $(\mathrm{K})$ processing complex of Bacillus subtilis and components of the type IV secretion system of Helicobacter pylori (Green \& Cutting, 2000; Hofreuter et al., 2003). As an example of special interest, we studied the membrane topology of HrcR in $E$. coli and in X. campestris pv. vesicatoria. All six reporter fusions adopted the same topology in both species, thus validating the approach of heterologous expression in E. coli.

The reporter fusion approach also relies on the assumption that C-terminal truncations of the protein under study do not affect its native topology, i.e. the formation and orientation of TMSs. This assumption appears to be justified because dozens of membrane proteins have been studied this way and many topology models were later confirmed by other biochemical approaches or high-resolution structures (van Geest \& Lolkema, 2000). However, a few studies indicate 
that fusion proteins can occasionally display an anomalous behaviour with respect to membrane topology (for a detailed discussion, see van Geest \& Lolkema, 2000). For instance, it is possible that more C-terminal transmembrane helices can influence the topology of more $\mathrm{N}$-terminal transmembrane helices (Ota et al., 1998; van Geest \& Lolkema, 1996). Such pitfalls guided the formulation of rules to optimize the reporter approach, as summarized by van Geest \& Lolkema (2000). It has been suggested that experimental support for a topological model requires a minimum of one fusion in each extra-membraneous domain. If the protein contains amino acid stretches of intermediate hydrophobicity that cannot unambiguously be predicted as membrane spanning, fusions should be made approximately every 30 residues. The use of PhoA as a reporter protein is advantageous because a positive result (i.e. enzymic activity) requires the export of the mature reporter enzyme moiety into the periplasm, while the use of LacZ as a cytoplasmic reporter may also give an enzymic activity as a result of artefacts, such as jamming of the export machinery. Throughout our study, we followed the rules of van Geest \& Lolkema (2000). We are thus confident that our topology models are correct.

\section{Concluding remarks}

Electron microscopy experiments have unravelled the morphology of some nonflagellar T3S systems (Blocker et al., 2001; Kubori et al., 1998; Marlovits et al., 2004), but a detailed understanding of the structural characteristics, organization and precise molecular organization of T3S systems is still lacking. Here, we present what is believed to be the first complete model of the inner membrane topology of a T3S system, which is based on a bioinformatics consensus prediction and experimentally derived constraints, including 129 different enzymically active reporter fusions. Our models validate and revise older models of T3S membrane proteins and will be instrumental for further model building, using X-rays, NMR and highresolution microscopy.

\section{ACKNOWLEDGEMENTS}

We thank Hannelore Espenhahn for excellent technical assistance, Antje Krüger (Martin-Luther-University, Halle) for providing the hrpX pBBR1-MCS5 derivative, Philipp Franken for comments on the manuscript, and Ernst Weber for fruitful discussions. We are very grateful to Mikhail F. Alexeyev and Herbert H. Winkler (University of South Alabama) for the Tnpholac mutagenesis system. This work was funded in part by grant KO 1686/3-2 from the Deutsche Forschungsgemeinschaft to R. K.

\section{REFERENCES}

Aizawa, S. I. (2001). Bacterial flagella and type III secretion systems. FEMS Microbiol Lett 202, 157-164.

Alexeyev, M. F. \& Winkler, H. H. (2002). Transposable dual reporters for studying the structure-function relationships in membrane proteins: permissive sites in $R$. prowazekii ATP/ADP translocase. Biochemistry 41, 406-414.

Allaoui, A., Woestyn, S., Sluiters, C. \& Cornelis, G. R. (1994). YscU, a Yersinia enterocolitica inner membrane protein involved in Yop secretion. J Bacteriol 176, 4534-4542.

Bertani, G. (1951). Studies on lysogenesis. I. The mode of phage liberation by lysogenic Escherichia coli. J Bacteriol 62, 293-300.

Blocker, A., Jouihri, N., Larquet, E., Gounon, P., Ebel, F., Parsot, C., Sansonetti, P. \& Allaoui, A. (2001). Structure and composition of the Shigella flexneri 'needle complex', a part of its type III secreton. Mol Microbiol 39, 652-663.

Bogdanove, A. J., Beer, S. V., Bonas, U., Boucher, C. A., Collmer, A., Coplin, D. L., Cornelis, G. R., Huang, H. C., Hutcheson, S. W. \& other authors (1996). Unified nomenclature for broadly conserved hrp genes of phytopathogenic bacteria. Mol Microbiol 20, 681-683.

Bonas, U., Stall, R. E. \& Staskawicz, B. (1989). Genetic and structural characterization of the avirulence gene avrBs3 from Xanthomonas campestris pv. vesicatoria. Mol Gen Genet 218, 127-136.

Bonas, U., Schulte, R., Fenselau, S., Minsavage, G. V., Staskawicz, B. J. \& Stall, R. E. (1991). Isolation of a gene cluster from Xanthomonas campestris pv. vesicatoria that determines pathogenicity and the hypersensitive response on pepper and tomato. Mol Plant Microbe Interact 4, 81-88.

Boyd, D., Manoil, C. \& Beckwith, J. (1987). Determinants of membrane protein topology. Proc Natl Acad Sci U S A 84, 8525-8529.

Büttner, D. \& Bonas, U. (2006). Who comes first? How plant pathogenic bacteria orchestrate type III secretion. Curr Opin Microbiol 9, 193-200.

Büttner, D., Nennstiel, D., Klüsener, B. \& Bonas, U. (2002). Functional analysis of HrpF, a putative type III translocon protein from Xanthomonas campestris pv. vesicatoria. J Bacteriol 184, 2389-2398.

Calamia, J. \& Manoil, C. (1990). lac permease of Escherichia coli: topology and sequence elements promoting membrane insertion. Proc Natl Acad Sci U S A 87, 4937-4941.

Coburn, B., Sekirov, I. \& Finlay, B. B. (2007). Type III secretion systems and disease. Clin Microbiol Rev 20, 535-549.

Cornelis, G. R. (2006). The type III secretion injectisome. Nat Rev Microbiol 4, 811-825.

Creasey, E. A., Delahay, R. M., Daniell, S. J. \& Frankel, G. (2003). Yeast two-hybrid system survey of interactions between LEE-encoded proteins of enteropathogenic Escherichia coli. Microbiology 149, 2093 2106.

Deane, J. E., Graham, S. C., Mitchell, E. P., Flot, D., Johnson, S. \& Lea, S. M. (2008). Crystal structure of Spa40, the specificity switch for the Shigella flexneri type III secretion system. Mol Microbiol 69, 267-276.

Dmitrova, M., Younes-Cauet, G., Oertel-Buchheit, P., Porte, D., Schnarr, M. \& Granger-Schnarr, M. (1998). A new LexA-based genetic system for monitoring and analyzing protein heterodimerization in Escherichia coli. Mol Gen Genet 257, 205-212.

Durocher, D. \& Jackson, S. P. (2002). The FHA domain. FEBS Lett 513, 58-66.

Edqvist, P. J., Olsson, J., Lavander, M., Sundberg, L., Forsberg, A., Wolf-Watz, H. \& Lloyd, S. A. (2003). YscP and YscU regulate substrate specificity of the Yersinia type III secretion system. J Bacteriol 185, 2259-2266.

Elofsson, A. \& von Heijne, G. (2007). Membrane protein structure: prediction versus reality. Annu Rev Biochem 76, 125-140.

Fadouloglou, V. E., Tampakaki, A. P., Glykos, N. M., Bastaki, M. N., Hadden, J. M., Phillips, S. E., Panopoulos, N. J. \& Kokkinidis, M. (2004). Structure of $\mathrm{HrcQ}_{B}-\mathrm{C}$, a conserved component of the bacterial type III secretion systems. Proc Natl Acad Sci U S A 101, 70-75. 
Fan, F., Ohnishi, K., Francis, N. R. \& Macnab, R. M. (1997). The FliP and FliR proteins of Salmonella typhimurium, putative components of the type III flagellar export apparatus, are located in the flagellar basal body. Mol Microbiol 26, 1035-1046.

Ferris, H. U. \& Minamino, T. (2006). Flipping the switch: bringing order to flagellar assembly. Trends Microbiol 14, 519-526.

Fields, K. A., Plano, G. V. \& Straley, S. C. (1994). A low- $\mathrm{Ca}^{2+}$ response (LCR) secretion ( $y s c$ ) locus lies within the $\operatorname{lcr} B$ region of the LCR plasmid in Yersinia pestis. J Bacteriol 176, 569-579.

Fraser, G. M., Hirano, T., Ferris, H. U., Devgan, L. L., Kihara, M. \& Macnab, R. M. (2003). Substrate specificity of type III flagellar protein export in Salmonella is controlled by subdomain interactions in FlhB. Mol Microbiol 48, 1043-1057.

Galan, J. E. \& Wolf-Watz, H. (2006). Protein delivery into eukaryotic cells by type III secretion machines. Nature 444, 567-573.

Ghosh, P. (2004). Process of protein transport by the type III secretion system. Microbiol Mol Biol Rev 68, 771-795.

Green, D. H. \& Cutting, S. M. (2000). Membrane topology of the Bacillus subtilis pro- $\sigma^{\mathrm{K}}$ processing complex. J Bacteriol 182, 278-285.

Gürlebeck, D., Thieme, F. \& Bonas, U. (2006). Type III effector proteins from the plant pathogen Xanthomonas and their role in the interaction with the host plant. J Plant Physiol 163, 233-255.

Guzman, L. M., Belin, D., Carson, M. J. \& Beckwith, J. (1995). Tight regulation, modulation, and high-level expression by vectors containing the arabinose $\mathrm{P}_{\mathrm{BAD}}$ promoter. J Bacteriol 177, 4121-4130.

He, S. Y. \& Jin, Q. (2003). The Hrp pilus: learning from flagella. Curr Opin Microbiol 6, 15-19.

He, S. Y., Nomura, K. \& Whittam, T. S. (2004). Type III protein secretion mechanism in mammalian and plant pathogens. Biochim Biophys Acta 1694, 181-206.

Hofreuter, D., Karnholz, A. \& Haas, R. (2003). Topology and membrane interaction of Helicobacter pylori ComB proteins involved in natural transformation competence. Int J Med Microbiol 293, $153-$ 165.

Huguet, E., Hahn, K., Wengelnik, K. \& Bonas, U. (1998). hpaA mutants of Xanthomonas campestris pv. vesicatoria are affected in pathogenicity but retain the ability to induce host-specific hypersensitive reaction. Mol Microbiol 29, 1379-1390.

Ikeda, M., Arai, M., Lao, D. M. \& Shimizu, T. (2002). Transmembrane topology prediction methods: a re-assessment and improvement by a consensus method using a dataset of experimentally-characterized transmembrane topologies. In Silico Biol 2, 19-33.

Jones, D. T. (2007). Improving the accuracy of transmembrane protein topology prediction using evolutionary information. Bioinformatics 23, 538-544.

Käll, L., Krogh, A. \& Sonnhammer, E. L. (2004). A combined transmembrane topology and signal peptide prediction method. $J \mathrm{Mol}$ Biol 338, 1027-1036.

Koebnik, R., Krüger, A., Thieme, F., Urban, A. \& Bonas, U. (2006), Specific binding of the Xanthomonas campestris pv. vesicatoria AraCtype transcriptional activator $\operatorname{HrpX}$ to plant-inducible promoter boxes. J Bacteriol 188, 7652-7660.

Kovach, M. E., Elzer, P. H., Hill, D. S., Robertson, G. T., Farris, M. A., Roop, R. M., II \& Peterson, K. M. (1995). Four new derivatives of the broad-host-range cloning vector pBBR1MCS, carrying different antibiotic-resistance cassettes. Gene 166, 175-176.

Krogh, A., Larsson, B., von Heijne, G. \& Sonnhammer, E. L. (2001). Predicting transmembrane protein topology with a hidden Markov model: application to complete genomes. J Mol Biol 305, 567-580.

Kubori, T., Matsushima, Y., Nakamura, D., Uralil, J., Lara-Tejero, M., Sukhan, A., Galan, J. E. \& Aizawa, S. I. (1998). Supramolecular structure of the Salmonella typhimurium type III protein secretion system. Science 280, 602-605.

Lavander, M., Sundberg, L., Edqvist, P. J., Lloyd, S. A., Wolf-Watz, H. \& Forsberg, A. (2002). Proteolytic cleavage of the FlhB homologue YscU of Yersinia pseudotuberculosis is essential for bacterial survival but not for type III secretion. J Bacteriol 184, 4500-4509.

Lorenz, C., Kirchner, O., Egler, M., Stuttmann, J., Bonas, U. \& Büttner, D. (2008a). HpaA from Xanthomonas is a regulator of type III secretion. Mol Microbiol 69, 344-360.

Lorenz, C., Schulz, S., Wolsch, T., Rossier, O., Bonas, U. \& Büttner, D. (2008b). HpaC controls substrate specificity of the Xanthomonas type III secretion system. PLoS Pathog 4, e1000094.

Marlovits, T. C., Kubori, T., Sukhan, A., Thomas, D. R., Galan, J. E. \& Unger, V. M. (2004). Structural insights into the assembly of the type III secretion needle complex. Science 306, 1040-1042.

McCann, H. C. \& Guttman, D. S. (2008). Evolution of the type III secretion system and its effectors in plant-microbe interactions. New Phytol 177, 33-47.

McMurry, J. L., Van Arnam, J. S., Kihara, M. \& Macnab, R. M. (2004). Analysis of the cytoplasmic domains of Salmonella FlhA and interactions with components of the flagellar export machinery. J Bacteriol 186, 7586-7592.

Melen, K., Krogh, A. \& von Heijne, G. (2003). Reliability measures for membrane protein topology prediction algorithms. J Mol Biol 327, 735-744.

Minamino, T. \& Macnab, R. M. (2000a). Domain structure of Salmonella FlhB, a flagellar export component responsible for substrate specificity switching. J Bacteriol 182, 4906-4914.

Minamino, T. \& Macnab, R. M. (2000b). Interactions among components of the Salmonella flagellar export apparatus and its substrates. Mol Microbiol 35, 1052-1064.

Minamino, T., lino, T. \& Kutuskake, K. (1994). Molecular characterization of the Salmonella typhimurium flhB operon and its protein products. J Bacteriol 176, 7630-7637.

Moraes, T. F., Spreter, T. \& Strynadka, N. C. (2008). Piecing together the type III injectisome of bacterial pathogens. Curr Opin Struct Biol 18, 258-266.

Nguyen, L., Paulsen, I. T., Tchieu, J., Hueck, C. J. \& Saier, M. H., Jr (2000). Phylogenetic analyses of the constituents of type III protein secretion systems. J Mol Microbiol Biotechnol 2, 125-144.

Nilsson, J., Persson, B. \& von Heijne, G. (2000). Consensus predictions of membrane protein topology. FEBS Lett 486, 267-269.

Ohnishi, K., Fan, F., Schoenhals, G. J., Kihara, M. \& Macnab, R. M. (1997). The FliO, FliP, FliQ, and FliR proteins of Salmonella typhimurium: putative components for flagellar assembly. J Bacteriol 179, 6092-6099.

Ota, K., Sakaguchi, M., Hamasaki, N. \& Mihara, K. (1998). Assessment of topogenic functions of anticipated transmembrane segments of human band 3. J Biol Chem 273, 28286-28291.

Pallen, M. J., Beatson, S. A. \& Bailey, C. M. (2005). Bioinformatics, genomics and evolution of non-flagellar type-III secretion systems: a Darwinian perspective. FEMS Microbiol Rev 29, 201-229.

Plano, G. V. \& Straley, S. C. (1995). Mutations in $y s c C, y s c D$, and $y s c G$ prevent high-level expression and secretion of $\mathrm{V}$ antigen and Yops in Yersinia pestis. J Bacteriol 177, 3843-3854.

Plano, G. V., Barve, S. S. \& Straley, S. C. (1991). LcrD, a membranebound regulator of the Yersinia pestis low-calcium response. J Bacteriol 173, 7293-7303.

Pourcher, T., Bibi, E., Kaback, H. R. \& Leblanc, G. (1996). Membrane topology of the melibiose permease of Escherichia coli studied by melB-phoA fusion analysis. Biochemistry 35, 4161-4168. 
Preston, G. M. (2007). Metropolitan microbes: type III secretion in multihost symbionts. Cell Host Microbe 2, 291-294.

Pühler, A., Arlat, M., Becker, A., Göttfert, M., Morrissey, J. P. \& O'Gara, F. (2004). What can bacterial genome research teach us about bacteria-plant interactions? Curr Opin Plant Biol 7, 137-147.

Rossier, O., Wengelnik, K., Hahn, K. \& Bonas, U. (1999). The Xanthomonas Hrp type III system secretes proteins from plant and mammalian bacterial pathogens. Proc Natl Acad Sci U S A 96, 93689373.

Rossier, O., Van den Ackerveken, G. \& Bonas, U. (2000). HrpB2 and HrpF from Xanthomonas are type III-secreted proteins and essential for pathogenicity and recognition by the host plant. Mol Microbiol 38, 828-838.

Rost, B., Yachdav, G. \& Liu, J. (2004). The PredictProtein server. Nucleic Acids Res 32, W321-W326.

Saijo-Hamano, Y., Minamino, T., Macnab, R. M. \& Namba, K. (2004). Structural and functional analysis of the C-terminal cytoplasmic domain of FlhA, an integral membrane component of the type III flagellar protein export apparatus in Salmonella. J Mol Biol 343, 457466.

Saijo-Hamano, Y., Imada, K., Minamino, T., Kihara, M., Macnab, R. M. \& Namba, K. (2005). Crystallization and preliminary X-ray analysis of the C-terminal cytoplasmic domain of FlhA, a membrane-protein subunit of the bacterial flagellar type III protein-export apparatus. Acta Crystallogr Sect F Struct Biol Cryst Commun 61, 599-602.

Sekiya, K., Ohishi, M., Ogino, T., Tamano, K., Sasakawa, C. \& Abe, A. (2001). Supermolecular structure of the enteropathogenic Escherichia coli type III secretion system and its direct interaction with the EspAsheath-like structure. Proc Natl Acad Sci U S A 98, 11638-11643.

Simon, R., Priefer, U. \& Pühler, A. (1983). A broad host range mobilization system for in vivo genetic engineering: transposon mutagenesis in Gram negative bacteria. Nat Biotechnol 1, 784-791.

Sorg, I., Wagner, S., Amstutz, M., Müller, S. A., Broz, P., Lussi, Y., Engel, A. \& Cornelis, G. R. (2007). YscU recognizes translocators as export substrates of the Yersinia injectisome. EMBO J 26, 3015-3024.

Spreter, T., Yip, C. K., Sanowar, S., André, I., Kimbrough, T. G., Vuckovic, M., Pfuetzner, R. A., Deng, W., Yu, A. C. \& other authors (2009). A conserved structural motif mediates formation of the periplasmic rings in the type III secretion system. Nat Struct Mol Biol 16, 468-476.

Tamano, K., Aizawa, S., Katayama, E., Nonaka, T., Imajoh-Ohmi, S., Kuwae, A., Nagai, S. \& Sasakawa, C. (2000). Supramolecular structure of the Shigella type III secretion machinery: the needle part is changeable in length and essential for delivery of effectors. EMBO J 19, 3876-3887.

Tampakaki, A. P., Fadouloglou, V. E., Gazi, A. D., Panopoulos, N. J. \& Kokkinidis, M. (2004). Conserved features of type III secretion. Cell Microbiol 6, 805-816.

Thieme, F., Koebnik, R., Bekel, T., Berger, C., Boch, J., Büttner, D., Caldana, C., Gaigalat, L., Goesmann, A. \& other authors (2005). Insights into genome plasticity and pathogenicity of the plant pathogenic bacterium Xanthomonas campestris pv. vesicatoria revealed by the complete genome sequence. J Bacteriol 187, 72547266.

Tusnady, G. E. \& Simon, I. (2001). The HMMTOP transmembrane topology prediction server. Bioinformatics 17, 849-850.

Ujwal, M. L., Jung, H., Bibi, E., Manoil, C., Altenbach, C., Hubbell, W. L. \& Kaback, H. R. (1995). Membrane topology of helices VII and XI in the lactose permease of Escherichia coli studied by lacY-phoA fusion analysis and site-directed spectroscopy. Biochemistry 34, 1490914917. van Geest, M. \& Lolkema, J. S. (1996). Membrane topology of the sodium ion-dependent citrate carrier of Klebsiella pneumoniae. Evidence for a new structural class of secondary transporters. J Biol Chem 271, 25582-25589.

van Geest, M. \& Lolkema, J. S. (2000). Membrane topology and insertion of membrane proteins: search for topogenic signals. Microbiol Mol Biol Rev 64, 13-33.

Van Gijsegem, F., Gough, C., Zischek, C., Niqueux, E., Arlat, M., Genin, S., Barberis, P., German, S., Castello, P. \& Boucher, C. (1995). The hrp gene locus of Pseudomonas solanacearum, which controls the production of a type III secretion system, encodes eight proteins related to components of the bacterial flagellar biogenesis complex. Mol Microbiol 15, 1095-1114.

Van Gijsegem, F., Vasse, J., De Rycke, R., Castello, P. \& Boucher, C. (2002). Genetic dissection of Ralstonia solanacearum hrp gene cluster reveals that the $\mathrm{HrpV}$ and $\mathrm{HrpX}$ proteins are required for Hrp pilus assembly. Mol Microbiol 44, 935-946.

von Heijne, G. (1986). The distribution of positively charged residues in bacterial inner membrane proteins correlates with the transmembrane topology. EMBO J 5, 3021-3027.

von Heijne, G. (1992). Membrane protein structure prediction. Hydrophobicity analysis and the positive-inside rule. J Mol Biol 225, 487-494.

von Heijne, G. (2006). Membrane-protein topology. Nat Rev Mol Cell Biol 7, 909-918.

Weber, E., Ojanen-Reuhs, T., Huguet, E., Hause, G., Romantschuk, M., Korhonen, T. K., Bonas, U. \& Koebnik, R. (2005). The type IIIdependent Hrp pilus is required for productive interaction of Xanthomonas campestris pv. vesicatoria with pepper host plants. J Bacteriol 187, 2458-2468.

Weber, E., Berger, C., Bonas, U. \& Koebnik, R. (2007). Refinement of the Xanthomonas campestris pv. vesicatoria $h r p D$ and $h r p E$ operon structure. Mol Plant Microbe Interact 20, 559-567.

Wengelnik, K. \& Bonas, U. (1996). HrpXv, an AraC-type regulator, activates expression of five of the six loci in the hrp cluster of Xanthomonas campestris pv. vesicatoria. J Bacteriol 178, 3462-3469.

Wengelnik, K., Marie, C., Russel, M. \& Bonas, U. (1996a). Expression and localization of HrpA1, a protein of Xanthomonas campestris pv. vesicatoria essential for pathogenicity and induction of the hypersensitive reaction. J Bacteriol 178, 1061-1069.

Wengelnik, K., Van den Ackerveken, G. \& Bonas, U. (1996b). HrpG, a key $h r p$ regulatory protein of Xanthomonas campestris pv. vesicatoria is homologous to two-component response regulators. Mol Plant Microbe Interact 9, 704-712.

Yip, C. K., Kimbrough, T. G., Felise, H. B., Vuckovic, M., Thomas, N. A., Pfuetzner, R. A., Frey, E. A., Finlay, B. B., Miller, S. I. \& Strynadka, N. C. (2005). Structural characterization of the molecular platform for type III secretion system assembly. Nature 435, 702-707.

Yun, C. H., Van Doren, S. R., Crofts, A. R. \& Gennis, R. B. (1991). The use of gene fusions to examine the membrane topology of the Lsubunit of the photosynthetic reaction center and of the cytochrome $b$ subunit of the $b c_{1}$ complex from Rhodobacter sphaeroides. J Biol Chem 266, 10967-10973.

Zarivach, R., Deng, W., Vuckovic, M., Felise, H. B., Nguyen, H. V., Miller, S. I., Finlay, B. B. \& Strynadka, N. C. (2008). Structural analysis of the essential self-cleaving type III secretion proteins EscU and SpaS. Nature 453, 124-127.

Zhu, K., Gonzalez-Pedrajo, B. \& Macnab, R. M. (2002). Interactions among membrane and soluble components of the flagellar export apparatus of Salmonella. Biochemistry 41, 9516-9524.

Edited by: C. A. Boucher 